\title{
Effect of Raw Sewage on Surface Water Quality in Opobo Town, Nigeria
}

\author{
Eunice MacPepple ${ }^{1}$, Ngozikaa Okereke ${ }^{1}$, Celestine Egwuonwu ${ }^{1}$, Asinyetogha H. Igoni ${ }^{2, *}$ \\ ${ }^{1}$ Department of Agricultural and Bio-Resources Engineering, Federal University of Technology, Nigeria \\ ${ }^{2}$ Department of Agricultural and Environmental Engineering, Rivers State University of Science and Technology, Nigeria \\ *Corresponding Author: ahigoni@yahoo.com
}

Copyright $\bigcirc 2017$ by authors, all rights reserved. Authors agree that this article remains permanently open access under the terms of the Creative Commons Attribution License 4.0 International License

\begin{abstract}
This study investigated the effect of raw sewage on the quality of surface water in Opobo town, Rivers State, Nigeria. The investigation was occasioned by the predominance of direct disposal of raw sewage into surface water bodies in the study area. Opobo town is a coastal community in the Niger Delta area of Nigeria; and in coastal communities, surface water contamination by fecal and organic matter is a primary water quality issue, especially in inland rivers. In the study, samples of surface water were collected with $500 \mathrm{ml}$ bottles at seven different points, ranging from the upstream to the downstream of the river. The samples were analyzed for twenty-two different water quality parameters, including turbidity, suspended solids, $\mathrm{pH}$, alkalinity, ammonia nitrogen, dissolved oxygen, biochemical oxygen demand (BOD) and chemical oxygen demand (COD), with the following mean values respectively obtained: $5.6 \mathrm{NTU}, 359.3 \mathrm{mg} / \mathrm{l}, 5.8,164.1 \mathrm{mg} / 1,146.3 \mathrm{mg} / \mathrm{l}$, $204.7 \mathrm{mg} / \mathrm{l}$ and $262.7 \mathrm{mg} / \mathrm{l}$. There were also substantial doses of total coliform $(172.3 \mathrm{cfu} / 100 \mathrm{ml})$, E. coli $(110.5$ $\mathrm{cfu} / 100 \mathrm{ml})$, Enterobacter $(106.0 \mathrm{cfu} / 100 \mathrm{ml})$ and salmonella spp $(162.7 \mathrm{cfu} / 100 \mathrm{ml})$. These results were compared with standard criteria for coastal waters designated for aquatic life, recreation, navigation, and industrial water supply. It was found that the discharge of raw sewage into the surrounding surface waters in the area presented water quality that is injurious to both human and aquatic life. The practice is strongly discouraged and treatment of the sewage before disposal also strongly recommended.
\end{abstract}

Keywords Raw Sewage, Surface Water Quality, Coastal Communities, Sewage Disposal Method, Opobo Town, Faecal Matter

\section{Introduction}

Surface waters in seas and oceans make up $96.5 \%$ of the earth's waters [1]. Surface waters are important because they house aquatic animals, act as an extra source to groundwater and support human economy in the areas of fishing, hunting, recreation, transportation, manufacturing and agriculture [2]. Achieving standard surface water quality in Nigeria has been, and is still a challenge. This is easily attributable to observable poor sanitation practices, especially related to disposal of untreated wastewater and sewage directly into the rivers, streams, seas and oceans. About $95 \%$ of households in the riverine or coastal areas in Nigeria have little or no wastewater sanitation facility, especially in the area of domestic waste disposal. This poor sanitation and unsafe disposal of waste, including human excreta and other bodily fluids, directly into surface waters defaces the water body, elicits offensive odors and has the potency to negatively affect human health, as the populace may be exposed to infectious diseases; and the aquatic life suffers. Storm water and other overland flow also contribute to polluting the surface water bodies due to the presence of solid waste on the ground surface.

To properly estimate the extent of pollution caused surface water, proper assessment of its quality has to be carried out based on accepted water quality standards. In Nigeria, water quality standards were developed by the Federal Environmental Protection Agency (FEPA) in 1988 to protect public health and enhance the quality of surface waters. FEPA compared data with that of some developed and developing countries as well as the World Health Organization [3]. In Opobo town, there is no evidence of established surface water quality and its correlation with standard requirements. This study was conducted to find out the physiochemical and microbiological properties of surface waters surrounding Opobo town into which different kinds of wastes are discharged.

\subsection{Sanitation Situation in Opobo Town}

There are various communal practices in Opobo town and her neighboring villages that are apparently detrimental to the environment, especially to human and aquatic health, as they negate established global best environmental practices. Right from 1870 till date raw sewage is being discharged 
directly into the water bodies surrounding Opobo town. In recent times, only about $5 \%$ of the households have some form of well-developed and acceptable sanitary system. However, $95 \%$ of these systems channel their untreated waste through pipes and gutters directly into the surface waters. (With these statistical details, you need to state your authority). Other solid wastes like papers, plastic bags, empty cans, toilet papers, sanitary pads, etc, are also disposed indiscriminately into the surrounding water bodies, and these contribute to the overall pollution of the water; destruction of its aesthetics, and devaluation of the economic activities of the people.

The type of facility employed for toilets in Opobo town are structures built directly over the water along the shoreline (Figure 1), where raw sewage and other bodily fluids are expelled daily [4]. Wooden supports are constructed where people squat to defecate. Recent improvements have introduced concrete platforms that are usually sat on, especially by the elderly, although at great risk of a very high possibility of contacting various forms of infections.

Faecal matter affects the economic and ecological health of any water body [5]. Communities like Opobo town that do not have adequate sanitation facilities are exposed to high risk of excreta-related infections. Most susceptible to these diseases are children under 3 years [6]. These infectious diseases reportedly include cholera, diarrhea and typhoid fever. Deaths resulting from diarrhea are estimated to be between 1.6 and 2.5 million persons every year worldwide; and most of the affected are young children below the ages of five [7]. GESAMP [8] noted that contamination of the marine environment by sewage leads to diseases linked to bathing and swimming in marine waters and to the consumption of seafood. Waterborne pathogens are accidentally ingested when water is swallowed or food borne pathogens found in the tissues of fish and shellfish are consumed as seafood [9].

Another disease caused by this type of poor sanitation practice is dysentery, contracted through intestinal infestation of parasitic worms [10]. Other diseases are salmonellosis, shigellosis, gastric ulcers, giardiasis and amoebiasis. Additional dangers to the disposal of raw sewage into water bodies are skin diseases [11]. This is supported by the World Health Organization (WHO) that reported that bathing in polluted seas causes some 250 million cases of gastroenteritis and upper respiratory disease every year [12]. Wastewater has also been reported as an important determinant in diseases like schistosomiasis, trachoma, ascariasis, trichuriasis and hookworm disease, malaria, yellow fever, filariasis, dengue, hepatitis A and hepatitis E, typhoid, arsenicosis, fluorosis and legionellosis [13]. Jimenez et al [11] also reported that the disposal of raw sewage results in high intensity ascariasis infections comprised of cognitive impairment, severe dysentery and anemia.

Eutrophication is a negative outcome of the disposal of untreated wastewater into surface waters. Nutrients contained in human excreta produce phosphorus and nitrogen in the river. This increase in nutrients results in algal blooms, loss of oxygen, fish kills, loss of biodiversity, amongst other problems [14]. Additionally, this algal blooms causes some species of algae to produce biotoxins (natural poisons) that can be transferred through the food web, potentially harming higher-order consumers such as marine mammals and humans [9]. Alabaster and Lloyd [15] noted the harm caused fishes from suspended solids in surface water. They reported that fishes are killed and their growth reduced, and that fish eggs and larvae were hindered from full development, including a general reduction of available food for fishes.

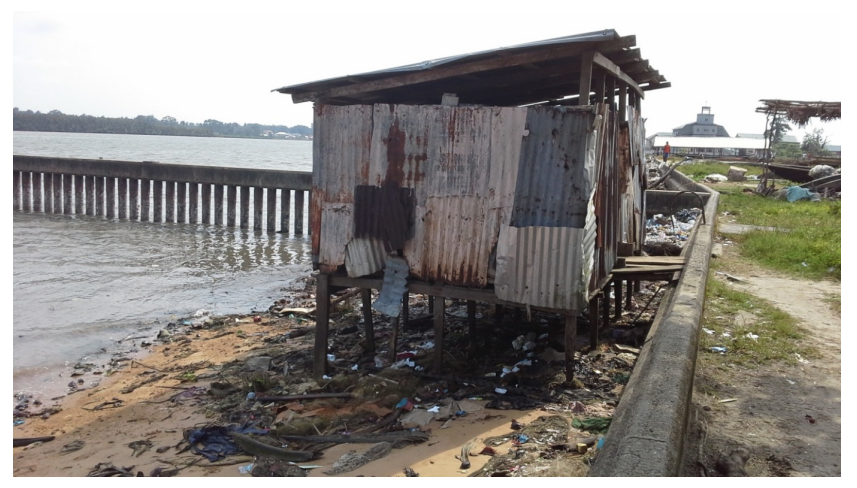

Figure 1. A typical toilet structure in Opobo town at ebb tide

\section{Materials and Methods}

\subsection{Study Area}

Opobo Town is the headquarters of Opobo/Nkoro Local Government Area of Rivers State, Nigeria. It is located at the southern part of Nigeria just beneath Ikot Abasi, Akwa Ibom State. It lies between latitude $4^{\circ} 30^{\prime} 41.11^{\prime \prime} \mathrm{N}$ and longitude $7^{\circ} 32^{\prime} 24.32^{\prime \prime}$ E. The town is inclusive in the total area of 130 $\mathrm{km}^{2}$ of the local government area, and has an average elevation of $4 \mathrm{~m}$ above sea level. Opobo town is bounded on the south by the Atlantic Ocean, on the north by Khana, east by Ikot Abasi and west by Andoni. A map of Opobo Town is shown in Figure 2.

Opobo Town as part of the Opobo Kingdom was founded in 1870 as a city state and played an important role in the palm oil trade because of her geographical location. The Opobo people are mainly farmers and fishermen who historically exchanged their smoke-dried fish and salt with the people of the hinterland for bulk foodstuffs, tools, clothing and domestic gear [16]. Opobo, as an ancient Kingdom, is made up of several Islands and communities, namely Opobo Town, Queenstown, Kalaibiama, Minima, Kala Sunju, Iloma, Ekereborokiri, Downbelow, and Epellema; while a part of the old city state, comprising of Ikot Abasi and Kampa, is now in Akwa Ibom State [17]. Her population, inclusive of the rest of the local government area was 170,527 persons [18]. 


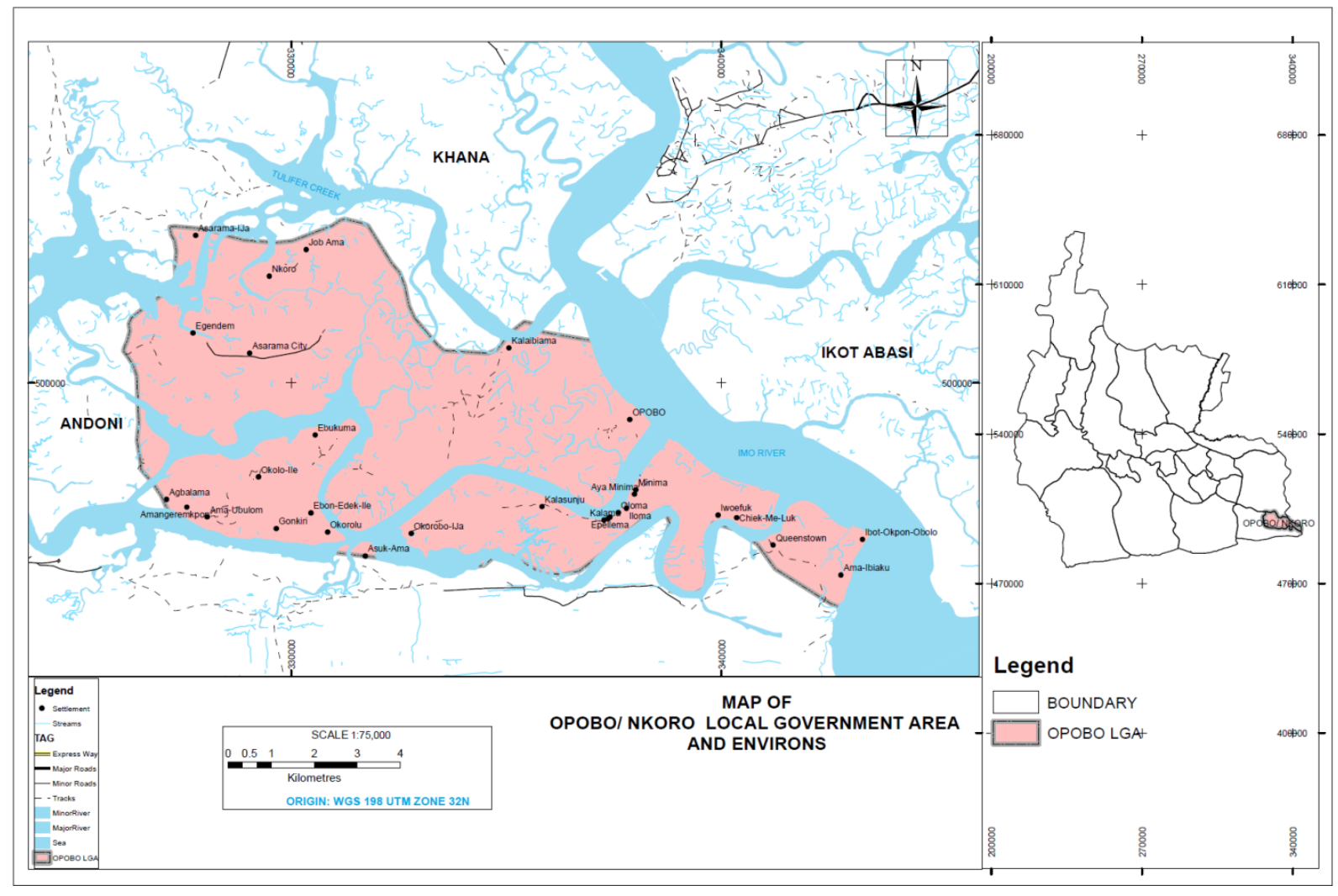

Figure 2. Map of Opobo Town

\subsection{Sampling}

Water samples were collected from the surface waters bordering the study area at different points on $17^{\text {th }}$ September 2015. The samples were taken from seven different locations. A total of twenty-one samples were taken, with three samples per location. Pre-treated $500 \mathrm{ml}$ bottles washed with $75 \%$ alcohol and rinsed with distilled water were used to collect the samples. The geographical coordinates at sample points were identified by means of a hand-held GPS (Garmin GPS $72 \mathrm{H}$ ). The samples were quickly transported to the laboratory for analysis.

\subsection{Surface Water Analysis}

The samples were analyzed to determine the presence of contaminants through their physical, chemical and microbiological properties at the Research Institute, Umudike, Abia State, Nigeria. The three samples collected from a given location were analyzed and the average values recorded as representative of that location. Twenty-two different water quality parameters were analyzed. Total alkalinity was determined by titration with sulphuric acid to a $\mathrm{pH}$ of 4.5 , the Nesslerization method was used to determine the ammonia nitrogen in the water; the metal, copper was measured using the Neocuprione method; Partition-gravimetric method was employed to determine the amount of oil and grease, and the Digestion and Ascorbic Acid Spectrophotometric method was used to determine the level of phosphorus. Other analytical methods were the Jackson candle turbidimeter for measuring the turbidity, titrimetric method for Biochemical oxygen demand and the closed reflux method using COD digester for the determination of the chemical oxygen demand in the water. Total coliform was determined by the multiple tube fermentation technique (MPN test), and the gravimetric method used for the identification of suspended and total solids, amongst other deterministic methods.

\section{Results and Discussion}

Tables 1, 2 and 3 show the results of the physical, biological and chemical parameters analyzed for the surface water samples. The surface water parameters were compared with the WHO and EPA standards and over $50 \%$ of the parameters investigated did not meet the international standards for surface waters.

\section{(i) Turbidity}

The average turbidity value in the characterization study exceeded the standard specification of 5NTU by 0.57 NTU. This deviation may seem intangible, but is a major cause of concern as any slight increase of turbidity (above 5 NTU) negatively affects fishes in the areas of feeding and avoidance of predators [15]. Increase in turbidity decreases 
penetration of sunlight for necessary plant growth, causing a reduction of food production; increases the water temperature leading to reduction of dissolved oxygen in the water, and causes physical stress in fish and decreased egg survival rates. Turbid waters generally affect the growth of some fish species, and cause abrasion of fish gills and clogging.

\section{(ii) Suspended Solids}

There was the presence of a mean of $359.3 \mathrm{mg} / \mathrm{l}$ amount of suspended solids at the sampling points, as against the acceptable standards of $30 \mathrm{mg} / \mathrm{l}$ for coastal waters. The effect of suspended solids on surface water include eutrophication, reduction of the penetration of sunlight for plant life; damage of the aquatic habitat, affecting fish life and formation of foreign deposits on the river beds resulting in septic and offensive conditions. The presence of suspended solids in surface water indicates the presence of sewage effluent discharges [19].

\section{(iii) Total Dissolved Solids (TDS)}

The TDS value at the study area was $668 \mathrm{mg} / \mathrm{l}$. The surface water in Opobo town, because of the discharges of untreated waste materials, especially raw sewage into it, can be described as brackish, following the findings of the authors in [20]. The amount of TDS is essential to the life of aquatic species, because if its concentration exceeds the naturally accepted standards, the density of water will increase thereby impacting on the flow of water that goes into and out of aquatic organisms. High concentrations of dissolved solids in surface waters affect the organism's ability to maintain the proper cell density, making it difficult to keep its position in the water column. Their growth is affected and death may occur. Changes in TDS concentrations also cause toxicity through increase in salinity, changes in the ionic composition of the water and toxicity of individual ions [21].

\section{(iv) Alkalinity and $\mathrm{pH}$}

The $\mathrm{pH}$ analyzed to be 5.8 is below the set standards for aquatic survival. Wilson [22] and Oram [23] reported that aquatic organisms thrive best in the presence of $\mathrm{pH}$ ranging between 6.0 and 9.0. The alkalinity was identified to have a mean of $164.1 \mathrm{mg} / \mathrm{l}$, surpassing the standard value of $20 \mathrm{mg} / \mathrm{l}$ by over $100 \%$. The alkalinity of a water body determines its capacity to self-regulate alterations in its acid content The degree of alkalinity in surface water determines the distribution of some aquatic species in the water medium. Higher alkalinity levels in surface waters will buffer acid rain and other acid wastes and prevents $\mathrm{pH}$ changes that are harmful to aquatic life. The alkalinity of a stream or other body of water is increased by carbonate-rich soils (carbonates and bicarbonates) such as limestone, and decreased by sewage outflow and aerobic respiration [24].

\section{(v) Oil and Grease}

Oil and grease include non-volatile hydrocarbons, vegetable oils, animal fats, waxes, soaps, greases, etc. At low concentrations, oil and grease is toxic to aquatic life as it reduces dissolved oxygen and alters the usefulness and aesthetics of the water body. The presence of Oil and grease in the study far exceeds (over 100\%) the allowable standard of $30 \mathrm{mg} / \mathrm{l}$ for surface waters.

\section{(vi) Salinity}

Excessive salinity of a water body negatively affects the health of the ecosystem, through a decline in biodiversity arising from the dominance of species that can tolerate the high salt levels. This causes an alteration in the ecosystem structures [25]. The water was found to be highly saline at $213.3 \mathrm{mg} / \mathrm{l}$.

\section{(vii) Phosphates}

Phosphates exist in three forms - orthophosphate, metaphosphate (polyphosphate) and organically bound phosphate. The Ortho forms are produced by natural processes and are found in sewage. Phosphates are important in any aquatic environment in order to stimulate the growth of plankton and aquatic plants which provide food for fish. But when phosphates occur in excess, algae and aquatic plants will grow wildly, choke up the waterway and use up large amounts of oxygen. This condition is known as eutrophication or over-fertilization of receiving waters. When the rapidly grown aquatic vegetation eventually dies and decays, it uses up large amounts of oxygen, thereby lowering the level of dissolved oxygen necessary for survival of aquatic species [26].

\section{(viii) Ammonia Nitrogen}

Ammonia is found in domestic wastewater because it is a decomposition product from urea and protein. $\mathrm{NH}_{3}$, which is the principal form of toxic ammonia, is toxic to fresh water organisms at concentrations ranging from 0.53 to $22.8 \mathrm{mg} / \mathrm{L}$. Hatching and growth rates of fishes may be affected. In the structural development, changes in tissues of gills, liver, and kidneys may also occur. Toxic concentrations of ammonia in humans may cause loss of equilibrium, convulsions, coma, and death [26].

\section{(ix) Sulphates}

The presence of sulphates was found to be in normal concentration, as it did not exceed the recommended level. It is important to not note that, among other sources, sulphates are result from sewage treatment plants and industrial discharges. The most common form of sulphur in well-oxygenated waters is sulphate. Aquatic organisms utilize sulphur. At reduced concentrations, sulphates have a detrimental effect on algal growth, because, when less than $0.5 \mathrm{mg} / \mathrm{L}$, algal growth will not occur [26]. 


\section{(x) Organic Compounds and Bacteria}

The chemical (organic and inorganic) and biological characteristics far exceeded the international standards of surface waters by WHO and the EPA. Indicator organisms of fecal contamination were found in the form of Enterococci, Escherichia coli and total coliform bacteria. Salmonella and Klebsiella were also present in the samples. The presence of these organisms means that the water is unsuitable for aquatic and recreational use. The BOD and COD in the water were also investigated and the average values also exceeded recommended standards (204.7 $\mathrm{mg} / 1$ and $262.7 \mathrm{mg} / \mathrm{l})$. Inorganic nitrogen and phosphorus were found to exceed the standards as well $(8.7 \mathrm{mg} / \mathrm{l}$ and $146.3 \mathrm{mg} / \mathrm{l})$, amongst other parameters.

\section{Conclusions}

The physical, chemical and biological analyses carried out for the surface waters bordering Opobo town showed concentrations of organics, solids and nutrients detrimental to aquatic and human health. The high levels of BOD, COD, nutrients and the coliform group of bacteria at the different sample points are indicative of the danger of direct discharges of raw sewage and other domestic wastes into the surrounding water body. To save human and aquatic life, it will be proper to undertake a comprehensive review of the management of waste, especially sewage, in Opobo town. This study recommends the development of an effective and efficient sewage and wastewater collection and treatment systems in the town. 
Table 1. Surface water physical properties

\begin{tabular}{|c|c|c|c|c|c|c|c|c|c|c|}
\hline & Sample No. & $\mathrm{A}$ & $\mathrm{B}$ & $\mathrm{C}$ & $\mathrm{D}$ & $\mathrm{E}$ & $\mathrm{F}$ & G & Criteria & \\
\hline Parameters & $\begin{array}{c}\text { Location } \\
\text { (Lat/Long) }\end{array}$ & $\begin{array}{l}4^{\circ} 30^{\prime} 46.88^{\prime \prime} \mathrm{N} \\
7^{\circ} 32^{\prime} 44.33^{\prime \prime} \mathrm{E}\end{array}$ & $\begin{array}{l}4^{\circ} 30^{\prime} 48.61^{\prime \prime} \mathrm{N} \\
7^{\circ} 32^{\prime} 34.65^{\prime \prime} \mathrm{E}\end{array}$ & $\begin{array}{l}4^{\circ} 30^{\prime} 59.67^{\prime \prime} \mathrm{N} \\
7^{\circ} 32^{\prime} 28.76^{\prime \prime} \mathrm{E}\end{array}$ & $\begin{array}{l}4^{\circ} 30^{\prime} 37.70^{\prime \prime} \mathrm{N} \\
7^{\circ} 32^{\prime} 29.71^{\prime \prime} \mathrm{E}\end{array}$ & $\begin{array}{l}4^{\circ} 30^{\prime} 15.89^{\prime \prime} \mathrm{N} \\
7^{\circ} 32^{\prime} 15.48^{\prime \prime} \mathrm{E}\end{array}$ & $\begin{array}{r}4^{\circ} 30^{\prime} 4.47^{\prime \prime} \mathrm{N} \\
7^{\circ} 32^{\prime} 17.85^{\prime \prime} \mathrm{E} \\
\end{array}$ & $\begin{array}{l}4^{\circ} 30^{\prime} 30.08^{\prime \prime} \mathrm{N} \\
7^{\circ} 32^{\prime} 59.04^{\prime \prime} \mathrm{E}\end{array}$ & WHO/EPA & Mean \\
\hline Turbidity (NTU) & & 5.6 & 5.3 & 5.6 & 5.4 & 5.6 & 5.7 & 5.8 & 5 & 5.6 \\
\hline Suspended Solids (mg/l) & & 287 & 382 & 403 & 318 & 503 & 324 & 298 & 30 & 359.3 \\
\hline TDS $(m g / l)$ & & 718 & 730 & 705 & 598 & 653 & 582 & 689 & 1000 & 667.9 \\
\hline $\mathrm{pH}$ & & 6.7 & 5.7 & 5.7 & 6.4 & 5.3 & 5.3 & 5.3 & 9 & 5.8 \\
\hline Alkalinity $(m g / l)$ & & 163 & 166 & 162 & 168 & 160 & 163 & 167 & 20 & 164.1 \\
\hline Oil and Grease $(m g / l)$ & & 58 & 67 & 60.2 & 58 & 63 & 69 & 62 & 10 & 62.5 \\
\hline Salinity $(\mathrm{mg} / \mathrm{l})$ & & 216 & 214 & 217 & 220 & 204 & 216 & 206 & 120 & 213.3 \\
\hline
\end{tabular}

Table 2. Surface water biological properties

\begin{tabular}{|c|c|c|c|c|c|c|c|c|c|c|}
\hline & Sample No. & $\mathbf{A}$ & B & C & D & $\mathbf{E}$ & $\mathbf{F}$ & G & Criteria & \\
\hline Parameters & $\begin{array}{c}\text { Location } \\
\text { (Lat/Long) }\end{array}$ & $\begin{array}{l}4^{\circ} 30^{\prime} 46.88^{\prime \prime} \mathrm{N} \\
7^{\circ} 32^{\prime} 44.33^{\prime \prime} \mathrm{E}\end{array}$ & $\begin{array}{l}4^{\circ} 30^{\prime} 48.61^{\prime \prime} \mathrm{N} \\
7^{\circ} 32^{\prime} 34.65^{\prime \prime} \mathrm{E}\end{array}$ & $\begin{array}{l}4^{\circ} 30^{\prime} 59.67^{\prime \prime} \mathrm{N} \\
7^{\circ} 32^{\prime} 28.76^{\prime \prime} \mathrm{E}\end{array}$ & $\begin{array}{l}4^{\circ} 30^{\prime} 37.70^{\prime \prime} \mathrm{N} \\
7^{\circ} 32^{\prime} 29.71^{\prime \prime} \mathrm{E} \\
\end{array}$ & $\begin{array}{l}4^{\circ} 30^{\prime} 15.89^{\prime \prime} \mathrm{N} \\
7^{\circ} 32^{\prime} 15.48^{\prime \prime} \mathrm{E} \\
\end{array}$ & $\begin{array}{r}4^{\circ} 30^{\prime} 4.47^{\prime \prime} \mathrm{N} \\
7^{\circ} 32^{\prime} 17.85^{\prime \prime} \mathrm{E} \\
\end{array}$ & $\begin{array}{l}4^{\circ} 30^{\prime} 30.08^{\prime \prime} \mathrm{N} \\
7^{\circ} 32^{\prime} 59.04^{\prime \prime} \mathrm{E}\end{array}$ & WHO/EPA & Mean \\
\hline $\operatorname{COD}(m g / l)$ & & 253 & 278 & 279 & 263 & 270 & 258 & 238 & 90 & 262.7 \\
\hline $\mathrm{BOD}(m g / l)$ & & 217 & 209 & 209 & 215 & 216 & 230 & 137 & 30 & 204.7 \\
\hline E-Coli $(c f u / 100 \mathrm{ml})$ & & 152 & 10.6 & 212 & & 152 & 26 & & 88 & 110.5 \\
\hline Enteroccoci $(c f u / 100 \mathrm{ml})$ & & & & & & 58 & 24 & & 33 & 11.7 \\
\hline
\end{tabular}

Table 3. Surface water Chemical properties

\begin{tabular}{|c|c|c|c|c|c|c|c|c|c|c|}
\hline & Sample No. & $\mathbf{A}$ & B & $\mathbf{C}$ & D & $\mathbf{E}$ & $\mathbf{F}$ & G & Criteria & \\
\hline Parameters & $\begin{array}{c}\text { Location } \\
\text { (Lat/Long) }\end{array}$ & $\begin{array}{l}4^{\circ} 30^{\prime} 46.88^{\prime \prime} \mathrm{N} \\
7^{\circ} 32^{\prime} 44.33^{\prime \prime} \mathrm{E} \\
\end{array}$ & $\begin{array}{l}4^{\circ} 30^{\prime} 48.61^{\prime \prime} \mathrm{N} \\
7^{\circ} 32^{\prime} 34.65^{\prime \prime} \mathrm{E} \\
\end{array}$ & $\begin{array}{l}4^{\circ} 30^{\prime} 59.67^{\prime \prime} \mathrm{N} \\
7^{\circ} 32^{\prime} 28.76^{\prime \prime} \mathrm{E} \\
\end{array}$ & $\begin{array}{l}4^{\circ} 30^{\prime} 37.70^{\prime \prime} \mathrm{N} \\
7^{\circ} 32^{\prime} 29.71^{\prime \prime} \mathrm{E} \\
\end{array}$ & $\begin{array}{l}4^{\circ} 30^{\prime} 15.89^{\prime \prime} \mathrm{N} \\
7^{\circ} 32^{\prime} 15.48^{\prime \prime} \mathrm{E} \\
\end{array}$ & $\begin{array}{r}4^{\circ} 30^{\prime} 4.47^{\prime \prime} \mathrm{N} \\
7^{\circ} 32^{\prime} 17.85^{\prime \prime} \mathrm{E}\end{array}$ & $\begin{array}{l}4^{\circ} 30^{\prime} 30.08^{\prime \prime} \mathrm{N} \\
7^{\circ} 32^{\prime} 59.04^{\prime \prime} \mathrm{E} \\
\end{array}$ & WHO/EPA & Mean \\
\hline Copper $(m g / l)$ & & 0.3 & 0.3 & 0.5 & 0.4 & 0.5 & 0.5 & 0.6 & 0.03 & 0.4 \\
\hline Potassium (mg/l) & & 9.3 & 9.8 & 10.6 & 10.1 & 12.1 & 19.6 & 10.9 & Nil & 11.8 \\
\hline Calcium $(m g / l)$ & & 11.3 & 10.4 & 11 & 11.6 & 10.7 & 11.8 & 12.3 & Nil & 11.3 \\
\hline Magnesium $(m g / l)$ & & 6.7 & 6.8 & 6.6 & 6.9 & 8 & 7.9 & 8.1 & Nil & 7.3 \\
\hline Lead $(m g / l)$ & & 0.6 & 0.7 & 0.5 & 0.6 & 0.4 & 0.3 & 0.4 & 0.2 & 0.5 \\
\hline Aluminium $(m g / l)$ & & 0.2 & 0.2 & 0.1 & 0.1 & 0.2 & 0.2 & 0.2 & 7.6 & 0.2 \\
\hline Zinc (mg/l) & & 0.7 & 0.7 & 0.5 & 0.5 & 0.4 & 0.6 & 0.4 & 0.1 & 0.6 \\
\hline Sulphates $(\mathrm{mg} / \mathrm{l})$ & & 21.3 & 21.3 & 25.6 & 28 & 20.5 & 23 & 24.3 & 100 & 23.4 \\
\hline Ammonia Nitrogen $(m g / l)$ & & 135 & 132 & 142 & 142 & 154 & 159 & 160 & 22.8 & 146.3 \\
\hline Residual Chlorine $(m g / l)$ & & 48.2 & 52.6 & 38 & 40 & 51 & 35.6 & 36 & 230 & 43.1 \\
\hline Phosphates $(m g / l)$ & & 8.4 & 8.1 & 9.3 & 10.4 & 10.2 & 6.9 & 7.3 & 0.1 & 8.7 \\
\hline
\end{tabular}




\section{REFERENCES}

[1] Gleick, P. H. Water in Crisis: A Guide to the World's Freshwater Resources. Oxford University Press, (1993). pp. 13.

[2] EPA. Water Quality Standards for Surface Waters. United States Environmental Protection Agency, Washington, D.C. http://www.Water.epa.gov/scitech/swguidance/standards/use s.cfm. (2013). Retrieved $23^{\text {rd }}$ September, 2015.

[3] Enderlein, U. S., R. E. Enderlein and W. P. Williams. Water Quality Requirements.www.who.int/water/ sanitation_health /resoucesquality/wpcchap2.pdf. (1985). Retrieved 23rd September, 2015.

[4] Cookey, P., B. A. Kokpan, M. R. Aguo, W. Wenes and P. C. John. (2008). "Assessment of Water Supply and Sanitation of some Coastal Communities of the Niger Delta," in 33rd WEDC International Conference, Accra, Ghana, pp. 383-385.

[5] Okereke, C. D. Environmental Pollution Control, (2006), pp. 52 .

[6] Mara, D. D., A. Sleigh and K. Tayler. PC-based simplified sewer design. University of Leeds, (2001), pp. 1-89

[7] Mara, D. D., J. Lane, B. Scott and D. Trouba. "Sanitation and health". PLoS medicine, 7(11), (2010), pp. 1359

[8] GESAMP. Protecting the Oceans from Land-based Activities Land-based Sources and Activities Affecting the Quality and Uses of the Marine, Coastal and Associated Freshwater Environment, GESAMP Reports and Studies 71. (2001)

[9] Water Encyclopedia, Science and Issues. Human health and Water, http://www.waterencyclopedia.com/Ge-Hy/HumanHealth-and-Water.html (2015)

[10] Abdel-Raouf, N., A.A. Al-Homaidan and I. B. M. Ibraheem. "Microalgae and Wastewater Treatment." Saudi Journal of Biological Sciences, (2012) pp. 258-259.

[11] Jimenez, B., Drechsel, P., Kone, D., Bahri, A., Liqu, R. and Qadir, M. Wastewater, Sludge and Excreta use in Developing countries: An Overview, (2008). pp. 5-9.

[12] The Caribbean Environment Program. Wastewater, Sewage and Sanitation, http://www.cep.unep.org/publications-and-resources/ marine-and-coastal-issues-links/wastewater-sewage-and sanitation, pp 1-3. Retrieved 11th February, 2015
[13] -Akali, D. M., D. B. Adie and O. T. Iorhemen.. "Comparative Analysis on the Use of Septic Tank and Sanitary Sewerage Systems at Malali Housing Estate, Kaduna-Nigeria." International Journal of Engineering Research and Technology, 1(9), (2012) pp. 1-2.

[14] Carpenter, S. R., N. F. Caraco, D. L. Correll, R. W. Howarth, A. N. Sharpley and V. H. Smith. "Nonpoint pollution of surface waters with phosphorus and nitrogen." Ecological applications, 8(3), (1998). pp. 559-568.

[15] Alabaster, J. S. and R. S. Lloyd. "Water quality criteria for freshwater fish." Elsevier. (2013)

[16] Jones, G. I. "The Trading States of the Oil Rivers - A Study of political development in Eastern Nigeria." International African Institute, (1963). pp. 49-63.

[17] Wikipedia the free encyclopaedia. Rivers State. https://en.wikipedia.org/wiki/Rivers_State

[18] Wikipedia the free encyclopaedia. Opobo-Nkoro. http://en.wikipedia.org/wiki/Opobo [April 22, 2015].

[19] EPA. Parameters of Water Quality: Interpretation and Standards.https://www.epa.ie/pubs/advice/water/quality/Wat er_Quality. pdf (2001)

[20] Weber-Scannell, P.K. and L.K. Duffy. "Effects of Total Dissolved Solids on Aquatic Organisms: A Review of Literature and Recommendation for Salmonid Species." American Journal of Environmental Sciences, 3 (1), (2007), pp 1-6.

[21] Murphy, S. General Information on Solids. USGS Water Quality Monitoring http://bcn.boulder.co.us/basin/data/NEW /info/TDS.html. (2007)

[22] Wilson, P. C (2010), Water Quality Notes: Alkalinity and Hardness. The Institute of Food and Agricultural Sciences (IFAS), https://edis.ifas.ufl.edu/ss540.

[23] Oram, B. The Role of Alkalinity Citizen Monitoring. Water Research Center,http://www.water-research.net/index.php/th e -role-of-alkalinity-citizen-monitoring (2014)

[24] Kemker, C. pH of Water. Fundamentals of Environmental Measurements (2013)

[25] Australian Government, Department of the Environment: Salinity and Water Quality. https://www.environment.gov.au /water/quality/publications/factsheet-salinity-and-water-quali ty. (2012)

[26] Kentucky River Basin Assessment Report. WQ Parameter, http://www.uky.resources/Watersedu/WaterRhed/KRBAR/ krww_parameters (2015) 